\title{
PENERAPAN PEMBELAJARAN E-BISNIS SISWA PKBM PAJA MANDIRI PADA PEMBUATAN PROTOTIPE SISTEM RUMAH MAKAN MASAKAN PADANG KUTABUMI
}

\author{
Arief Herdiansah $^{1}$, Yani Sugiyani ${ }^{2}$, Ri Sabti Septarini ${ }^{3}$ \\ ${ }^{1,2,3}$ Universitas Muhammadiyah Tangerang / Fakultas Teknik, Teknik Informatika \\ Jl. Perintis Kemerdekaan 1/33 Cikokol Kota Tangerang TLP. 55793251 \\ Email: arief_herdiansah@umt.ac.id ${ }^{1}$, yani.sugiyani@ft-umt.ac.id ${ }^{2}$, risabtis@ft-umt.ac.id ${ }^{3}$
}

Article history

Received May 11, 2020

Revised May 19, 2019

Accepted May 26, 2019

Available online May 31, 2020

Keywords

e-Business,

Restaurant

SIPOC,

PKBM.

\begin{abstract}
Padang menus restaurant business is one of the many culinary businesses that we find in Indonesia, especially in Tangerang. Padang business restaurant competition is also quite tight, to be able to increase sales of Padang menus offered by the Padang Kutabumi restaurant, the researchers develop a prototype of a web-based food ordering system at the Padang restaurant located near the PKBM Paja Mandiri location. Data collection methods used in this research were interviews and observations to the restaurant, the analysis system method used SIPOC, the system design method using SDLC using UML diagrams. To get the best results that users want, developed applications are tested with black box testing. The application of e-business is expected to improve service to customers, can increase food sales at the Kutabumi Padang restaurant and is one of the ebusiness lessons for Paja Mandiri PKBM students.
\end{abstract}

\begin{abstract}
Abstrak
Bisnis rumah makan masakan padang merupakan salah satu bisnis kuliner yang banyak kita jumpai di Indonesia khususnya di Tangerang. Persaingan bisnis rumah makan padang juga cukup ketat, untuk dapat meningkatkan penjualan masakan padang yang ditawarkan rumah makan padang Kutabumi, peneliti membuat sebuah prototipe sistem pemesanan makanan berbasis web pada rumah makan padang yang terdapat dekat dengan lokasi PKBM Paja Mandiri. Metode pengumpulan data yang digunakan dalam penelitian ini adalah wawancara dan observasi ke rumah makan tersebut, metode analisis sistem yang digunakan adalah SIPOC metode perancangan sistem menggunakan SDLC dengan menggunakan diagram UML. Untuk mendapatkan hasil yang diinginkan pengguna, aplikasi yang dikembangkan diuji dengan black box testing. Penerapan e-bisnis ini diharapkan dapat meningkatkan pelayanan pada pelanggan, dapat meningkatkan penjualan makanan di rumah makan padang Kutabumi dan merupakan salah satu pembelajaran e-bisnis bagi siswa PKBM Paja Mandiri.
\end{abstract}

\section{PENDAHULUAN}

Masakan padang (Sumatra Barat) merupakan salah satu kuliner khas Indonesia yang banyak penggemarnya, hal itu mendorong banyak perantau jadi wilayan sumatera barat membuka dan menjalankan bisnis masakan padang, salah satunya rmah makan masakan padang kutabumi di Kabupaten Tangerang.

Dalam rangka membantu rumah makan padang Kutabumi dan dalam rangka memberikan pembelajaran penerapan ebisnis kepada siswa PKBM Paja Mandiri, peneliti mencoba membuat sebuah e-bisnis dalam bentuk prototipe sistem pemesanan makanan di rumah makan padang kutabumi Tangerang.

Menurut Handarkho, dkk (2017), pemanfaatan strategi e-business saat ini juga banyak dilakukan oleh pelaku usaha mikro kecil menengah (UMKM) sebagai bagian dari strategi bisnis yang diharapkan mampu meningkatkan performa bisnis UMKM mereka.

Pemanfaatan teknologi informasi dalam menjalani sebuah bisnis/usaha sangatlah penting, 
Arkemen, dkk (2013) mengatakan Ketersediaan informasi yang cepat,

Tepat, akurat akan dapat memperlancar serta dapat mempermudah terjadinya sebuah transaksi bisnis. Oleh karena itu penting bagi sebuah UMKM menerapkan e-bisnis dalam menjalani roda bisnisnya.

Berdasarkan hal diatas, peneliti merasa perlu membantu untuk mengembangkan prototipe sistem pemesanan makanan di rumah makan masakan padang kutabumi di Kabupaten Tangerang.

Dalam proses menjalankan usaha rumah makan masakan padang kutabumi, saat ini ada beberapa kendala yang dihadapi, antara lain:

- Pelanggan dapat melakukan pemesanan makanan melalui telepon (HP) dan itu cukup Pemilik cukup kerepotan dan mengganggu aktivitas pemilik dalam menjani pekerjaan.

- Pemilik sering kali harus melayani pertanyaan akan ketersediaan beberapa menu masakan melalui telepon (HP) dan hal tersebut juga cukup mengganggu aktivitas pemilik rumah makan..

- Pelanggan yang melakukan telepon (HP) dan SMS/WA terkadang lama terlayani karena kesibukan pemilik dalam menjalani usaha rumah makan.

Permasalahan dalam penelitian ini dirumuskan sebagai berikut:

- Bagaimana membuat desain prototipe sistem pemesanan masakan di rumah makan masakan padang kutabumi?

- Bagaimana mengimplementasikan dan menguji prototipe sistem pemesanan masakan di rumah makan masakan padang kutabumi?

- Bagaimana dapat menjadikan proses pengembangan dan implementasi prototipe sistem ini sebagai bentuk pembelajaran siswa PKBM Paja Mandiri dalam pembelajaran ebisnis?

\section{TINJAUAN PUSTAKA}

\section{Definisi e-bisnis}

Zhao, et.all (2015) mengatakan, eBusiness telah secara luas diterima untuk transaksi bisnis yang dilakukan secara elektronik. Dengan keberhasilan eBusiness, perusahaan secara signifikan mengurangi upaya untuk pengolahan data, meningkatkan akurasi data bisnis, dan menemukan model atau pelanggan baru.

ndou., et.all (2010) mengatakan, solusi digital dapat memungkinkan sebuah usaha/ perusahaan untuk secara lebih efisien membeli, menjual, dan mengelola proses rantai pasokan dan penjualan dalam skala lebih luas/global.

Berdasarkan beberapa hal diatas, $E$ Business dapat dikatakan sebagai sebuah kegiatan/aktivitas menjalankan bisnis di internet, bukan saja kegiatan pembelian dan penjualan barang dan jasa tetapi juga termasuk pelayanan pelanggan serta kerja sama dengan rekan bisnis usaha yang dijalankan.

\section{Definisi Metode Waterfall}

Metode waterfall adalah sebuah metode pembangunan sistem informasi yang memberikan gambaran pendekatan yang sistematis serta berurutan pada pengembangan perangkat lunak, dimulai dengan komunkasi kebutuhan pengguna, tahapan perencanaan, permodelan, konstruksi serta penyerahan sistem ke pengguna yang diakhiri dengan dukungan pada perangkat lunak lengkap yang dihasilkan/after implementation support. Pressman (2015).

Dalam penerapannya, metode waterfall terdiri dari beberapa tahapan aktivitas yang harus dilakukan pengembang sistem informasi, aktivitas tersebut dapat dilihat pada gambar 1.1. berikut ini:

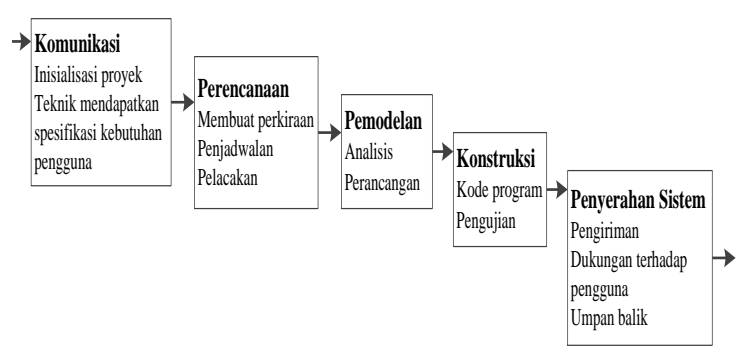

Gambar 1. Tahapan Model Waterfall 


\section{System Development Life Cycle (SDLC)}

Salahuddin (2018) mendefinisikan SDLC atau Software Development Life Cycle atau sering disebut juga System Development Life Cycle sebagai proses mengembangkan atau mengubah suatu sistem perangkat lunak dengan menggunakan model-model dan metodologi yang digunakan untuk mengembangkan perangkat lunak sebelumnya berdasarkan best practice atau cara-cara yang sudah teruji baik.

SDLC merupakan tahapan-tahapan proses yang dilakukan dalam proses pengembangan sistem informasi berbasis komputer.

\section{PHP Framework Laravel}

PHP merupakan sebuah bahasa pemrograman server side karena PHP diproses pada server, PHP bukanlah bahasa pemrograman client-side seperti JavaScript yang diproses pada web browser (client).

Dalam bahasa Inggris, framework bisa didefinisikan sebagai kerangka kerja, dalam sebuah bahasa pemrograman frmawork merupakan kerangka kerja dan struktur konseptual dasar yang bisa digunakan untuk memecahkan permasalahan dan isu-isu kompleks menggunakan pemrograman berbasis komputer.

Menurut Aminudin (2015) Laravel adalah sebuah Framework PHP dirilis dibawah lisensi MIT dengan kode sumber yang sudah disediakan oleh Github, sama seperti framework-framework yang lain, Laravel dibangun dengan konsep MVC (Model-Controller-View), kemudian Laravel dilengkapi juga command line tool yang bernama "Artisan" yang bisa digunakan untuk packaging bundle dan instalasi bundle melalui command prompt.

\section{Tinjauan Studi}

Beberapa tinjauan studi yang peneliti gunakan dalam penelitian ini antara lain:

- Penelitian yang dilakukan oleh Perkasa, Kridalukmana dan Widiyanto (2016) yang berjudul "Perancangan Sistem Manajemen Restoran dengan Aplikasi Pemesanan Restoran berbasis Mobile dalam Jeringan Lokal". Penelitian ini merupakan penelitian untuk pengembangan sistem informasi manajemen di sebuah restoran. Metode pengembangan sistem menggunakan model waterfall, dengan menggunakan bahasa pemrograman PHP. Sistem informasi yang dikembangkan telah dapat mengelola data pesanan pelanggan, stok barang, menu makanan dan minuman serta mengelola tagihan pembayaran.

- Penelitian yang dilakukan oleh Dharmaadi dan Sasmitha (2018), yang berjudul "Perancangan Sistem Informasi Restoran Terintegrasi Berbasis Java Web Socket Online". Penelitian ini merupakan sebuah penelitian pengembangan sistem informasi restoran yang didasari untuk Mendapatkan laporan kinerja penjualan secara cepat dan akurat ditengah persaingan usaha restoran yang semakin ketat. Metodologi yang digunakan adalah metode SDLC (System Development Life Cycle). Sistem informasi yang dikembangkan telah dapat membuat restoran dapat memberikan pelayanan yang memuaskan bagi pelanggan.

- Penelitian yang dilakukan oleh Widiyanto (2011), yang berjudul "Analisis dan Perancangan Sistem Informasi Restoran pada Restoran Nasi Goreng Bakar $\mathrm{Mr}$ Puencheng Yogyakarta". Penelitian ini dilakukan dengan tujuan membuat Sistem Informasi penjualan untuk sebuah restoran sehingga akan dapat membantu meningkatkan layanan pelanggan Nasi Goreng Bakar Mr. Puencheng Restaurant dan dapat memudahkan dalam membuat laporan penjualan yang lebih baik serta pengelolaan pembelian stok bahan masakan. Sistem yang dihasilkan telah dapat membatu pemilik restoran mengelola restoran dengan lebih baik, sistem telah dapat menghasilkan beberapa informasi diantaranya menampilkan informasi daftar menu habis sehingga dapat memberikan info dengan cepat kepada pengguna sehingga dapat disampaikan ke pelanggan bahwa untuk menu-menu tersebut sedang habis.

\section{METODOLOGI PENELITIAN}

Jenis Penelitian

Penelitian yang dilakukan merupakan sebuah penelitian terapan dengan menggunakan metode pengembangan sistem SDLC dan telah dijalan dengan terstruktur, penelitian ini menggunakan model pembangunan sistem waterfall. 


\section{Metode Pemilihan Sample}

Penelitian ini menggunakan metode pemilihan sample purposive sampling. Teknik pengambilan sampel dilakukan dengan mengambil data dari responden yang dipilih peneliti berdasarkan ciri-ciri spesifik responden yang telah ditentukan peneliti.

\section{Metode Pengumpulan Data}

Metode pengumpulan data yang digunakan peneliti antara lain melakukan wawancara/intervivew kepada nara sumber yang telah ditentukan sebelumnya untuk melihat kebutuhan pengembangan sistem pemesanan makanan di rumah makan masakan padang kutabumi.

\section{Teknik Analisis Sistem}

Teknik analisis sistem yang digunakan peneliti adalah analisis SIPOC (Supplier - Inputs -Process - Outputs - Customer) yang diharapkan dapat menganalisa suatu permasalahan dengan rinci dilihat dari segi pemasok (dalam hal ini pelanggan, masukan, proses, pengeluaran.

Tabel 1. Analisis SIPOC

\begin{tabular}{|c|c|c|c|c|}
\hline $\begin{array}{l}\text { Suppli } \\
\text { er }\end{array}$ & Input & $\begin{array}{l}\text { Proces } \\
s\end{array}$ & $\begin{array}{l}\text { Outp } \\
\text { ut }\end{array}$ & $\begin{array}{l}\text { Custome } \\
r\end{array}$ \\
\hline $\begin{array}{l}\text { Pelang } \\
\text { gan }\end{array}$ & $\begin{array}{l}\text { 1. Data } \\
\text { Pelangg } \\
\text { an } \\
\text { 2. Data } \\
\text { menu } \\
\text { masakan } \\
\text { 3. Data } \\
\text { Pesanan } \\
\text { menu } \\
\text { makana } \\
n\end{array}$ & $\begin{array}{l}\text { Penye } \\
\text { diaan } \\
\text { menu } \\
\text { makan } \\
\text { yang } \\
\text { dipesa } \\
\mathrm{n}\end{array}$ & $\begin{array}{l}\text { Lapo } \\
\text { ran } \\
\text { peme } \\
\text { sana } \\
\mathrm{n} \\
\text { maka } \\
\text { na }\end{array}$ & $\begin{array}{l}\text { Pelangg } \\
\text { an yang } \\
\text { memesa } \\
\mathrm{n} \text { menu } \\
\text { makana } \\
\mathrm{n}\end{array}$ \\
\hline
\end{tabular}

\section{Desain Penelitian}

Berikut ini desain diagram UML (Unified Modeling Language) yang dibuat dalam rangka mengembangkan prototipe sistem rumah makan masakan padang kutabumi Kabupaten Tangerang.

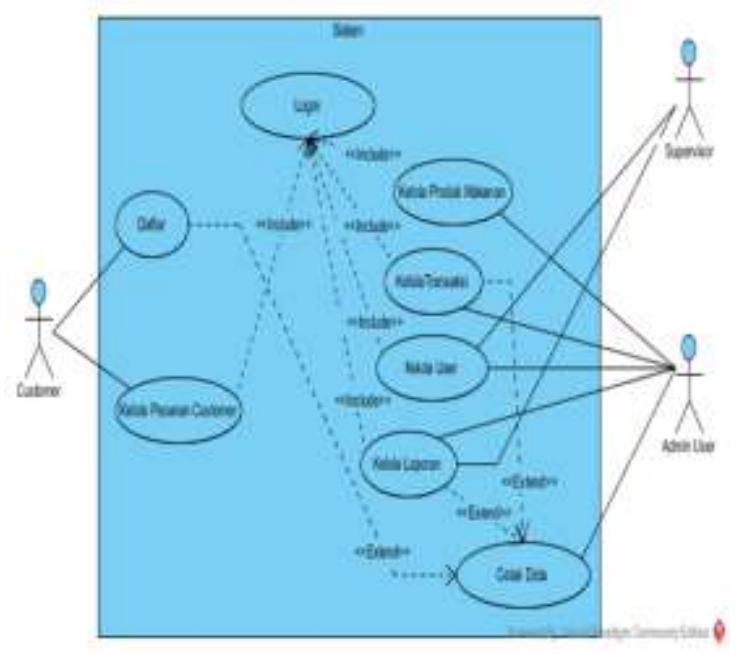

Gambar 2. Diagram Use Case

Dalam gambar diagram use case diatas dapat dilihat terdapat 3 aktor yang akan menggunakan prototipe sistem dimana aktor customer/pelanggan merupakan aktor utama yang akan banyak berinteraksi dengan sistem yang dikembangkan.

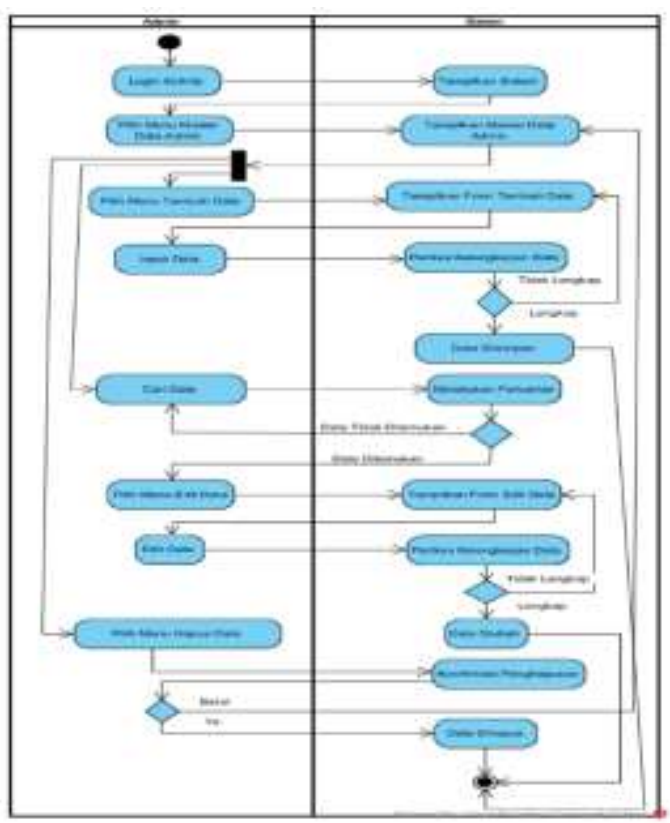

Gambar 3. Diagram Activity 


\section{HASIL DAN PEMBAHASAN}

\section{Tampilan Login}

Bagi pengguna yang akan masuk ke dalam sistem pengguna harus login, tampilan menu login dapat dilihat dalam gambar berikut ini:

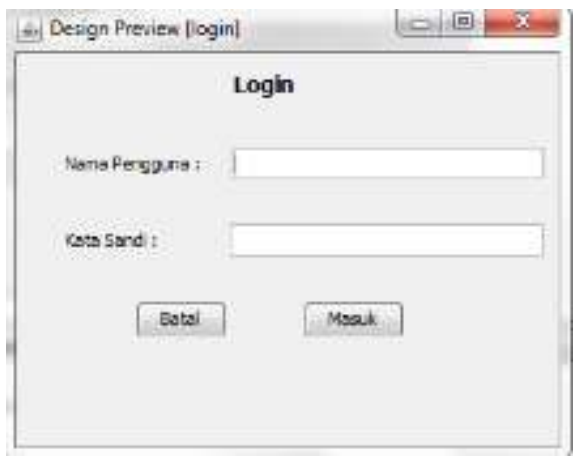

Gambar 4. Menu Login

\subsection{Tampilan Data Anggota}

Jika pengguna tidak dapat melakukan login, maka pengguna diwajibkan melakukan daftar sebagai pelanggan rumah makan sebagaimana tampilan berikut ini:

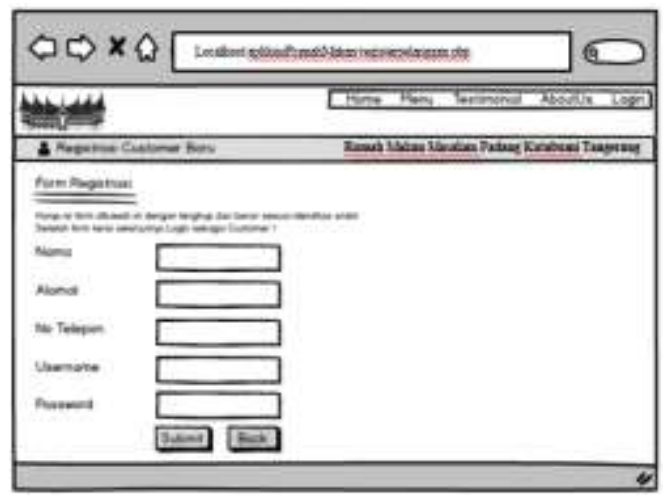

Gambar 5. Menu Pendaftaran

\subsection{Tampilan Data Menu}

Jika pelanggan telah berhasil masuk dalam sistem, pelanggan dapat memesan menu makanan sebaggaimana gambar berikut ini:

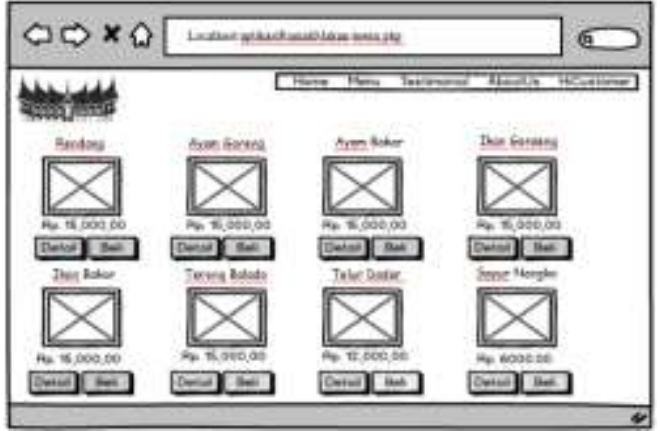

Gambar 6. Tampilan Pemesanan Menu Makanan

\section{Pengujian Sistem}

Pengujian prototipe sistem rumah makan masakan padang Kutabumi menggunakan metode pengujian black box dan dari telah menghasilkan sebuah laporan pengujian sistem sebagaimana tabel IV-1 berikut ini:

Tabel 2. Pengujian Black Box

\begin{tabular}{|c|c|c|}
\hline No & Proses & Hasil \\
\hline 1 & Login \& Logout & Valid \\
\hline 2 & Input \& Save data pelanggan & Valid \\
\hline 3 & Input \& Save data menu & Valid \\
\hline 4 & $\begin{array}{c}\text { Input \& Save data } \\
\text { pemesanan }\end{array}$ & Valid \\
\hline 5. & Hapus dan edit data & Valid \\
\hline 6 & Menampilkan data pelanggan & Valid \\
\hline 7 & $\begin{array}{c}\text { Menampilkan data makanan } \\
\text { Valid }\end{array}$ & Valid \\
\hline 8 & Menampilkan data pesanan & Valid \\
\hline 9 & Hapus data pesanan & Valid \\
\hline 12 & Edit \& Save data & Valid \\
\hline
\end{tabular}




\section{KESIMPULAN}

Kesimpulan yang dapat diambil dari hasil penelitian penerapan pembelajaran e-bisnis siswa PKBM Paja Mandiri pada pembuatan prototipe sistem rumah makan masakan padang kutabumi sebagai berikut:

- Perancangan prototipe sistem yang dikembangkan telah dilakukan dengan mengacu pada permintaan pemilik dan kebutuhan pelanggan sesuai dengan hasil wawancara dan observasi yang telah dilakukan.

- Sistem yang dirancang dan dikembangkan telah diuji coba bersama pengguna dan dianggap cukup memenuhi kebutuhan pengguna.

- Dalam proses pengembangan dan implementasi prototipe sistem rumah makan masakan padang Kutabumi, khususnya dalam proses pengumpulan data serta demo prototipe sistem yang telah dibuat, peneliti melibatkan siswa PKBM Paja Mandiri sebagai bentuk pembelajaran dan pengetahuan tentang ebisnis.

\section{DAFTAR PUSTAKA}

Aminudin. 2015. Pengantar Apresiasi Karya Sastra. Bandung: Sinar Baru Algensindo.

Erwin, Widiyanto. 2011. Analisis dan Perancangan Sistem Informasi Restoran pada Restoran Nasi Goreng Bakar Mr Puencheng Yogyakarta. Publikasi ilmiah STMIK Amikom Yogyakarta. http://repository.amikom.ac.id/files/Publika si_05.11.0964.pdf

Feng, Zhao., Guodong, Nian., Hai, Jin, Laurence, T, Yang., Yajun, Zhu. 2015. A Hybrid eBusiness Software Metrics Framework forDecision Making in Cloud Computing Environment. IEEE System Journal. pp. 1-11.

I, Putu, Arya, Dharmaadi., Gusti, Made, Arya, Sasmitha. 2018. Perancangan Sistem Informasi Restoran Terintegrasi Berbasis Java Web Socket Online. Jurnal Penelitian Pos \& Informatika, Badan Litbang SDM Kemenkoinfo. Vol 8 No 1.pp. 51-62.

Manggala, Raka, Perkasa., Rinta, Kridalukmana., Eko, Didik, Widiyanto. 2016. Perancangan Sistem Manajemen
Restoran dengan Aplikasi Pemesanan Restoran berbasis Mobile dalam Jeringan Lokal". Jurnal Teknologi dan Sistem Komputer, Vol 4 No.2, April. pp. 289-294.

Pressman, S.R, 2015, Rekayasa Perangkat Lunak-Pendekatan Praktisi Buku I, Yogyakarta, Andi

S, Shalahudin, 2015.Rekayasa Perangkat Lunak Terstruktur dan Berorientasi Objek. Bandung: Informatika.

Valentina, Ndou., Laura, Schina., Giuseppina, Passiante., Pasquale, Del, Vecchio., Marco, De, Maggio. 2010. Toward an Open etwork Business Approach. 4th IEEE International Conference on Digital Ecosystems and Technologies, 13-16 April. IEEE Journal. pp. 282-287.

Yandra, Arkeman., Ono, Suparno., Citra, Wanurmarahayu. 2013. Rancang Bangun Sistem Bisnis Berbasis Interner (E-Bisnis) untuk Agroindustri Kulit Smak (Leather). Jurnal Teknologi Industri Pertanian, IPB, Vol 23, No 2. pp. 142-152.

Yonathan, Dri, Handarkho., Timothy, Ryan, Suryanto., Findra, Kartika, Sari Dewi3., Eddy, Julianto. 2017. Penerapan Strategi Ebusiness Untuk Meningkatkan Keunggulan Kompetitif dari Usaha Mikro Kecil Menengah di Indonesia. Jurnal Buana Informatika, Universitas Atma Jaya Yogyakarta Vol 8 No. 4. pp. 201-212. 